\section{Forum: geographic spread and urbanization of visceral leishmaniasis in Brazil. Introduction}

\author{
Fórum: expansão geográfica e urbanização da \\ leishmaniose visceral no Brasil. Introdução
}

\author{
1 Escola Nacional de Saúde \\ Pública Sergio Arouca, \\ Fundação Oswaldo Cruz, \\ Rio de Janeiro, Brasil. \\ 2 Faculdade de Medicina, \\ Universidade Federal do Rio \\ de Janeiro, Rio de Janeiro, \\ Brasil. \\ Correspondence \\ G. L. Werneck \\ Departamento de Endemias \\ Samuel Pessoa, Escola \\ Nacional de Saúde Pública \\ Sergio Arouca, Fundação \\ Oswaldo Cruz. \\ Rua Leopoldo Bulhões 1480, \\ Rio de Janeiro, $R J$ \\ 21041-210, Brasil. \\ gwerneck@ensp.fiocruz.br
}

\begin{abstract}
The geographic spread and urbanization of visceral leishmaniasis in Brazil has been described since the early 1980s. However, the putative factors associated with this process, its full characterization, and the implications for disease control still challenge researchers and Public Health professionals. Although the available data show that the disease occurs mainly in urban areas, current knowledge is insufficient to claim specificity in urban transmission as compared to rural niches. Transmission scenarios in urban settings appear to be highly heterogeneous, each showing some degree of similarity to the rural epidemiological pattern. The understanding of a relatively recent and complex problem like the introduction, spread, and maintenance of visceral leishmaniasis in urban areas requires new analytical approaches that consider the network of relevant variables and more elaborate methods capable of capturing the dynamics of the environmental and demographic transformations taking place in transmission areas.
\end{abstract}

Communicable Disease Control; Disease Transmission; Urbanization; Visceral Leishmaniasis
Guilherme L. Werneck 1,2

Visceral leishmaniasis affects some 65 countries, with an estimated annual incidence of 500 thousand new cases and 50 thousand deaths 1,2 . In Brazil, visceral leishmaniasis is caused by the protozoan Leishmania (Leishmania) chagasi and is transmitted by sand flies of the genus Lutzomy$i a$, with dogs as the principal source of infection in urban areas 3 .

Historically known as a rural endemic, since the 1980s the disease has become endemic and epidemic in large Brazilian cities. In this slow process of urbanization, Teresina, State capital of Piauí, experienced the first major urban epidemic of visceral leishmaniasis in Brazil, with more than 1,000 cases reported from 1981 to $1986{ }^{4}$. Other epidemics were later described in Natal (Rio Grande do Norte) 5 and São Luis (Maranhão) 6 , followed by spread of the disease to cities in other regions of the country ${ }^{3}$.

This epidemiological panorama leaves no doubt about the severity of the situation and the full-blown geographic expansion of visceral leishmaniasis. From 1980 to 2004, 57,766 cases of visceral leishmaniasis were reported in Brazil, with 2,911 deaths 7 . In the five-year periods 1985 1989, 1990-1994, 1995-1999, and 2000-2004, the mean annual number of reported cases increased from 1,601 to $2,264,3,060$, and 3,630, respectively. In the 1990 s, only $10 \%$ of the reported cases occurred outside the Northeast Region, but from 2000 to 2004 more than $30 \%$ of cases were reported in the North, Central-West, and Southeast 
of the country ${ }^{7}$. In recent years, autochthonous transmission of visceral leishmaniasis was reported in more than 1,600 municipalities (counties) in 19 States, with a mean annual incidence of 2 cases/ 100 thousand inhabitants 3 .

The available data demonstrate the problem's magnitude, but appear insufficient to demonstrate that there is a typically urban characteristic of the disease. It is true that for various reasons, whether demographic (e.g.: migration), environmental (e.g.: environmental destruction facilitating direct contact between humans, natural vector breeding habitats, and wild reservoirs), or sanitary (e.g.: haphazard land occupation with precarious sanitation, favoring the vector's adaptation to the peridomestic environment), visceral leishmaniasis now occurs mostly in urban areas. However, this fact is insufficient to affirm that the epidemiological pattern has changed to the point of claiming specificity to the urban transmission as opposed to that occurring in the traditional rural niches that were extensively studied and characterized in Brazil in the 1950, specificity to the in the landscapes known as pé-de-serra (foothills), boqueirão (hollow), and grotão (grotto) 8,9,10,11.

Various alterations may have been induced by urbanization, such as changes in the degree of the vector's anthropophilia, the contribution of human-to-human transmission for maintaining endemic levels, an increase in the parasite's virulence, development of resistance to drugs and insecticides, etc. However, this question appears not to have been explored systematically, so it is still conceivable that the urbanization of visceral leishmaniasis has not produced relevant epidemiological modifications in the infection's natural history and that the typically rural ecological conditions have merely shifted to the cities. Still, this conjecture appears insufficient in light of the diversity of ecological situations in which visceral leishmaniasis occurs in Brazil. On the other hand, to admit that visceral leishmaniasis transmission in the urban setting presents peculiar aspects in each region would mean to deny the existence of some degree of biological and epidemiological unity in the process, which also appears unreasonable. An alternative hypothesis would be that transmission in the urban setting is heterogeneous, but governed by basic conditions that allow one to trace transmission scenarios or typologies, each with more or less distinct nuances, showing greater or lesser similarity to the rural epidemiological pattern.

A question that also merits attention is the definition per se of "urban" 12,13. In general, the notion of urbanization refers to changes in the size, density, and heterogeneity of cities 12 , but also the decrease in distances between similar cities and the increase in the population's mobility, segregation, and proximity between the poorest and the wealthiest ${ }^{13}$. However, the operationalization of the concept of "urban" displays wide diversity between regions and within countries, and can vary over time ${ }^{12}$. An analysis of the definitions of "urban" used by 228 countries allowed a classification in ten categories, varying from the mere use of population size to criteria that include political and administrative demarcation, the presence of public installations and buildings, supply of services, and economic activities 13 . Brazil is one of the few places in the world in which the urban area is defined by municipal law, with a wide variability in the criteria used. This heterogeneity is a limiting factor for obtaining estimates on the incidence of urban visceral leishmaniasis and especially for making comparisons between regions.

The variety of eco-epidemiological transmission scenarios originates from spatial heterogeneities in the distribution of vectors and other risk factors, different patterns in intra-urban vector-host contact, and variations in populations' susceptibility. Such heterogeneities have important epidemiological implications and can lead to a substantial increase in the force of transmission 14,15. In this situation, population subsets make a larger contribution to transmission, and targeting interventions on these groups can lead to a substantial reduction in infection rates.

It is thus crucial to consider these heterogeneities in transmission in different urban scenarios in order to properly support the choice of intervention strategies, since the effectiveness of control measures can be modified by various factors, like transmission level, the number of susceptible individuals, the size of the canine and vector populations, socioeconomic level, the peridomiciliary environment, and the physical space (microclimate, vegetation, altitude, relief, etc.). If the underlying heterogeneity in the location where the intervention is being implemented is a modulating factor for its effectiveness, it should follow that the preferential emphasis or implementation of one control measure as opposed to another is a strategic choice for each eco-epidemiological niche.

Thus, the understanding of a relatively recent and complex problem like the introduction, spread, and maintenance of visceral leishmaniasis in the urban environment requires analytical approaches that consider the intricate structure of variables, in addition to more elaborate methods for capturing the dynamics of demographic and environmental changes currently under way in transmission areas. The combination of multilevel models, statistical methods for the analysis 
of spatial-temporal data, geographic information systems, and remote sensing imagery can help deal with this challenge.

The articles comprising this Forum, prepared by renowned experts in the field, express different approaches and concepts on the geographic spread and urbanization of visceral leishmaniasis in Brazil. Maia-Elkhoury et al. 16 present national data and the perspective of those in charge of visceral leishmaniasis control. Rangel et al. 17 focus on the role of the vector Lu. longipalpis in the urbanization of visceral leishmaniasis. Oliveira et al. 18 discuss the subject based on the experience in Belo Horizonte, Minas Gerais State. Costa 19 presents several arguments on the potential mechanisms underlying this process. Finally, Nascimento et al. 20, in the Postscript, analyze the theme based on studies in the State of Rio Grande do Norte and the reflections raised in the articles.

\section{Resumo}

A expansão geográfica e urbanização da leishmaniose visceral no Brasil é um fenômeno notável desde a década de 1980. Entretanto, o detalhamento dos motivos relacionados a este processo, assim como sua própria caracterização e as implicações em termos de ações de controle da doença vêm desafiando pesquisadores e profissionais da área de Saúde Coletiva. Ainda que os dados disponíveis demonstrem que a doença ocorre majoritariamente em áreas urbanas, o conhecimento acumulado não permite afirmar que há suficiente particularidade na transmissão urbana, em contraposição àquela que ocorre nos tradicionais nichos rurais. O que parece existir é uma heterogeneidade nos cenários de transmissão em meio urbano, cada um deles com nuanças mais ou menos distintas, mostrando maior ou menor similaridade em relação ao padrão epidemiológico rural. A compreensão de um problema relativamente recente e complexo, como é a introdução, disseminação e manutenção da leishmaniose visceral em meio urbano, necessita de abordagens analíticas que considerem a estrutura intricada das variáveis envolvidas, além de métodos mais elaborados para captação da dinâmica das transformações demográficas e ambientais em curso nas áreas de transmissão.

Controle de Doenças Transmissíveis; Transmissão de Doença; Urbanização; Leishmaniose Visceral

\section{Acknowledgments}

G. L. Werneck was partially funded by Brazilian Council for Scientific and Technological Development (CNPq, proc. 483657/06-9; 410590/06-1; 308889/07-0). 


\section{References}

1. Desjeux P. Leishmaniasis: current situation and new perspectives. Comp Immunol Microbiol Infect Dis 2004; 27:305-18.

2. World Health Organization. The World Health Report. Geneva: World Health Organization; 2002.

3. Secretaria de Vigilância em Saúde, Ministério da Saúde. Manual de vigilância e controle da leishmaniose visceral. Brasília: Ministério da Saúde; 2003.

4. Costa CHN, Pereira HF, Araújo MV. Epidemia de leishmaniose visceral no Estado do Piauí, Brasil, 1980-1986. Rev Saúde Pública 1990; 24:361-72.

5. Jeronimo SM, Oliveira RM, Mckay S, Costa RM, Sweet J, Nascimento ET, et al. An urban outbreak of visceral leishmaniasis in Natal, Brazil. Trans R Soc Trop Med Hyg 1994; 88:386-8.

6. Silva AR, Viana GMC, Varonil C, Pires B, Nascimento MDSD, Costa JML. Leishmaniose visceral (Calazar) na ilha de São Luís, Maranhão, Brasil: evolução e perspectivas. Rev Soc Bras Med Trop 1997; 30:359-68.

7. Ministério da Saúde. Série histórica de óbitos e casos de doenças de notificação compulsória no Brasil (1980-2005). http://portal.saude.gov.br/portal/ saude/visualizar_texto.cfm?idtxt=25340 (accessed on $25 / \mathrm{Feb} / 2008$ ).

8. Pessoa SB, Silva LHP, Figueiredo J. Calazar endêmico em Jacobina (Estado da Bahia). Rev Bras Malariol Doenças Trop 1955; 7:245-50.

9. Deane LM. Leishmaniose visceral no Brasil. Estudos sobre reservatórios e transmissores realizados no Estado do Ceará. Rio de Janeiro: Serviço Nacional de Educação Sanitária; 1956.

10. Alencar JE, Holanda D, Cavalcante JDN. Calazar no Vale Jaguaribe, Ceará, 1955. Rev Bras Malariol Doenças Trop 1956; 8:33-47.

11. Martins AV, Brener Z, Mourão OT, Lima MM, Souza MA, Silva JE. Calazar autóctone em Minas Gerais. Rev Bras Malariol Doenças Trop 1956; 8:555-63.
12. Vlahov D, Galea S. Urbanization, urbanicity, and health. J Urban Health 2002; 79(4 Suppl 1):S1-12.

13. Utzinger J, Keiser J. Urbanization and tropical health: then and now. Ann Trop Med Parasitol 2006; 100:517-33.

14. Woolhouse ME, Dye C, Etard JF, Smith T, Charlwood JD, Garnett JP, et al. Heterogeneities in the transmission of infectious agents: implications for the design of control programs. Proc Natl Acad Sci U S A 1997; 94:338-42.

15. Smith DL, Dushoff J, McKenzie FE. The risk of a mosquito-borne infection in a heterogeneous environment. PLoS Biol 2004; 2:e368.

16. Maia-Elkhoury ANS, Alves WA, Sousa-Gomes ML, Sena JM, Luna EA. Visceral leishmaniasis in Brazil: trends and challenges. Cad Saúde Pública 2008; 24:2941-7.

17. Rangel EF, Vilela ML. Lutzomyia longipalpis (Diptera, Psychodidade, Phlebotominae) and urbanization of visceral leishmaniasis in Brazil. Cad Saúde Pública 2008; 24:2948-52.

18. Oliveira CDL, Morais MHF, Machado-Coelho GLL. Visceral leishmaniasis in large Brazilian cities: challenges for control. Cad Saúde Pública 2008; 24:2953-8.

19. Costa CHN. Characterization and speculations on the urbanization of visceral leishmaniasis in Brazil. Cad Saúde Pública 2008; 24:2959-63.

20. Nascimento ELT, Martins DR, Monteiro GR, Barbosa JD, Ximenes MFFM, Maciel BL, et al. Forum: geographic spread and urbanization of visceral leishmaniasis in Brazil. Postscript: new challenges in the epidemiology of Leishmania chagasi infection. Cad Saúde Pública 2008; 24:2964-7.

Submitted on 06/Mar/2008

Approved on 10/Mar/2008 